\title{
Noise-Induced Hearing Loss (NIHL) Risk Factors among Manufacturing Industry Workers: A Systematic Review
}

\section{Ananda Ajeng Hapsari}

Department of Public Health, Faculty of Medicine and Health Science, Universitas Jambi

David Kusmawan ( $\nabla$ kusmawandavid@gmail.com )

Department of Public Health, Faculty of Medicine and Health Science, Universitas Jambi

\section{Systematic Review}

Keywords: noise, hearing loss, NIHL, occupation, risk factors

Posted Date: June 24th, 2021

DOl: https://doi.org/10.21203/rs.3.rs-643998/v1

License: (c) (1) This work is licensed under a Creative Commons Attribution 4.0 International License.

Read Full License 


\section{Abstract}

Introduction : Noise-Induced Hearing Loss ( $\mathrm{NIHL})$ is an occupational disease caused by continuous longterm acute exposure to intense noise with a noise intensity level higher than $85 \mathrm{~dB}(\mathrm{~A})$. Noise being one of the potential hazard in the workplace, is the most common risk factor for health problems (22\%), after workplace injuries (40\%). The aim of this work is to synthesize evidence on risk factors related to NIHL among the manufacturing industries workers.

Methods: This systematic review was conducted in the electronic search trough databases: SCIENCE DIRECT, PUBMED and GOOGLE SCHOLAR using appropriate keywords related to the theme. The keywords used in the databases were: "faktor risiko noise induced hearing loss" "industri" for national database, "noise induced hearing loss" AND "risk factors" AND "industry" for international databases.

Results: 1.175 studies were identified from the search, thus 1.049 were screened following the removal of duplicates. Title and abstract were screened, resulting in 1.049 articles being removed, 212 articles left for full text assessment and 20 articles met the inclusion criteria.

Conclusion: Risk factors for NIHL among manufacturing industry workers include noise intensity, years of service, duration of exposure (hours), age, hypertension, risk behaviors and Hearing Protection Device (HPD) usage.

\section{Introduction}

Noise is one of the most underestimated hazards in the industry. High noise intensity occurs in many parts of the production process in factories that have machines, presses, compressors and/or other noise-producing equipment and tools (WHO, 2017a). The high intensity of noise in the workplace can be caused by the large amount of continuous noise with a wide frequency spectrum in the production work unit (Hidayat et al., 2019).

Workers exposed to high intensity noise may suffer from Noise Induced Hearing Loss (International Labour Organization, 2014). NIHL is an occupational disease caused by continuous long-term acute exposure to intense noise with a noise intensity level higher than $85 \mathrm{~dB}$ (Zamri et al., 2017; Amar et al., 2019).

It is estimated that $17 \%$ of adults aged $20-69$ years (approximately 26 million) have suffered permanent damage to their hearing as a result of excessive noise exposure (Centers for Disease Control and Prevention, 2020)

There are 22.4 million workers exposed to noise intensity which has potential hazards every day (WHO, 2017a). Noise being one of the potential hazard in the workplace, is the most common risk factor for health problems (22\%), after workplace injuries (40\%) (WHO, 2017b) 
In a nutshell, people suffering from cochlear nerve hearing loss are greatly disturbed by background noise. There are many things that make it easier for a person to suffer from hearing loss, including high noise intensity, high frequency, the working period, years of service and others (Suma'mur, 2014; Amar et al., 2019;WHO, 2015). Certain individual factors such as gender, age, race or ethnicity, genetics, and general health problems can also influence a worker's susceptibility to the effects of noise (Permenaker, 2018)

Ototoxic substances can interfere with ear function and thus may be a risk factor for NIHL(EU-OSHA, 2009). Smoking has a direct ototoxic effect (with nicotine effects) and triggers cochlear ischemia through several mechanisms, such as producing carboxy hemoglobin, inducing vasospasm, increasing blood viscosity and worsening arteriosclerosis and endothelial dysfunction. So that smoking is considered to worsen the function of the cochlea (Sari et al., 2017). A person who smokes and is in an environment with a high noise frequency has a three times greater risk of experiencing hearing loss (Suma'mur, 2014).

To date, NIHL is the only type of hearing loss that is completely preventable. Apparently NIHL is a significant health problem in Asia. It is more common in developing countries with economic consequences where the majority is located in South East Asia countries (Jamal et al., 2016; Zaw et al., 2020).

It can be caused by the industrialization in those countries that is not accompanied by protection, with a lack of preventive and curative health services and the lack of awareness of workers and job provider about NIHL (WHO, 2017a).

The overall aim of this systematic review is to synthesize evidence on risk factors related to NIHL among the manufacturing industries workers. The review aims to answer the following primary research question: "what are the Noise-Induced Hearing Loss (NIHL) risk factors that have a strong relation with the incidence of NIHL among manufacturing industries workers?"

\section{Methods}

\section{Literature search}

A systematic literature search was independently conducted to review the studies that are related to NIHL among manufacturing industries workers. Studies published up to Dec 2020 were included in the review. This study was conducted in the electronic search through datasbases: Google Scholar, Pubmed and Science Direct. To ensure the concept of NIHL was fully captured in the searches, the keywords used in the databases were: "noise induced hearing loss" AND "risk factors" AND "industry".

An example of the following search terms were: ("hearing loss, noise induced"[MeSH Terms] OR ("hearing" [All Fields] AND "loss" [All Fields] AND "noise induced" [All Fields]) OR noise-induced hearing loss" [All Fields] OR ("noise" [All Fields] AND "induced" [All Fields] AND "hearing"[All Fields] AND "loss"[All Fields]) OR "noise induced hearing loss" [All Fields]) AND ("risk factors" [MeSH Terms] OR ("risk" [All Fields] AND 
"factors" [All Fields]) OR "risk factors" [All Fields]) AND ("industrial development" [MeSH Terms] OR ("industrial" [All Fields] AND "development" [All Fields]) OR "industrial development" [All Fields] OR "industrialization" [All Fields] OR "industrialize" [All Fields] OR "industrialized" [All Fields] OR "industrializing" [All Fields] OR "industrially" [All Fields] OR "industrials" [All Fields] OR "industry" [MeSH Terms] OR "industry" [All Fields] OR "industrial" [All Fields] OR "industries" [All Fields] OR "industry s"[All Fields]).

\section{Inclusion \& exclusion criteria}

The study included the following: (1) research articles published from 2015-2020; (2) primary research studies; (3) studies that can be accessed in full text; (4) studies that discusses risk factors for $\mathrm{NIHL}$; (5) studies applied among the manufacturing industries workers; (6) studies written in English or Indonesian.

The exclusion criteria were as follows: (1) research article published in the journal predator; (2) studies on $\mathrm{NIHL}$ that was not associated with occupational hearing loss; (3) studies that was not associated on noise exposure with the auditory system; (4) studies on the clinical treatment of NIHL; (5) studies on animal experiments; (6) studies on NIHL in cells and genetics; (7) studies on noise with unclear or incomplete results or unclear description of subjects.

\section{Eligibility criteria}

Primary research that complied with the criteria will be included in this systematic review.

\section{Search strategy}

The Preferred Reporting Items for Systematic Reviews and Meta-Analyses (PRISMA) guidelines were followed in the design and execution of this study. The PRISMA flowchart is shown in (Fig.1)

\section{Study selection}

Filters such as studies written in English or Indonesian language and published over the last 6 years ( Jan 2015 - Dec 2020) were applied to identify studies. The search resulted in 1.175 articles, found 93 duplicate articles along with it. After excluding duplicates and non-relevant studies, 1049 articles were recorded for screening. Through screening process, 886 articles were excluded by irrelevant title, abstract and keywords. From a total of the remaining 163 articles, 63 full text articles were assessed for eligibility. 
And the result found that 43 articles were not studies applied among the manufacturing industries workers. Thus, 20 studies were included for the review (Fig. 1). In cases where multiple publications were produced from a single study, the paper with most comprehensive data was included.

\section{Data extraction}

Data extracted from the selected studies included, based on the following variables: author(s), year of publication, title, sample size, type of study, industry classification of the study, statistically significant risk factors and noise intensity.

\section{Data synthesis}

The diversity among the identified studies, in terms of the methods, sample sizes and various risk factors exposures, did not allow a meta-analysis to be conducted. Instead, a narrative summary of identified risk factors were performed in this study.

\section{Result}

\section{Search results}

1.175 studies were identified from the search, thus 1.049 were screened following the removal of duplicates. Title and abstract based screening resulted in 1.049 articles being removed, which resulting 212 articles left for full text assessment. In overall, 20 articles met the inclusion criteria (Fig. 1).

\section{Study characteristics}

From all the articles identified, $20(100 \%)$ articles were full text articles. The study designs noted within the review were: $(90 \%)$ were cross sectional studies while the rest were case control and longitudinal study.

The distribution of study geographies is described in Table. 2: the majority of the studies (85\%) were conducted in Southeast Asia, 1 study (5\%) was conducted in East Asia, 1 study (5\%) was conducted in West Asia and another study (5\%) was conducted in East Africa.

The studies identified were mainly conducted in 2019 (40\%). Followed by 2016 (25\%), 2020 (15\%), 2017 (10\%), 2015 (5\%) and 2018 (5\%), which can be seen in (Fig. 2). 
Additionally, the distribution of where the studies were performed can be seen in Table 3: whereas the industries classification were divided into 10 categories of manufacturing industries.

\section{Risk factor identification}

The majority of studies analysed $(n=16,80 \%)$, identified more than one statistically significant risk factors for NIHL. and the rest $(n=4,20 \%)$ only stated noise intensity as statistically significant NIHL risk factor. The results of this grouping is shown in Table 4, which represents a complete list of all statistically significant risk factors identified within the published research literature, alongside the number (and references) of studies,which identified these risk factors as significant NIHL risk factors.

All of the papers used statistical tests to assess the impact of potential risk factors and evaluate their significance. Statistical significance level was set at a standard of p-value less than 0.05 .

Table 1 Distribution of study design

\begin{tabular}{ccc}
\hline Study Design & Number of Papers & Percentage of Papers (\%) \\
\hline Cross Sectional Study & 18 & 90 \\
\hline Case Control \& Comparative Study & 1 & 5 \\
\hline Longitudinal Study & 1 & 5 \\
\hline
\end{tabular}

Table 2 Distribution of study geographies

\begin{tabular}{cc}
\hline Study Location & \# studies \\
\hline Indonesia & 14 \\
Malaysia & 1 \\
Thailand & 1 \\
China & 1 \\
Myanmar & 1 \\
Iran & 1 \\
Tanzania & 1 \\
\hline
\end{tabular}

Table 3 Distribution of study based on the industry classification 


\begin{tabular}{cc}
\hline Industry Classification & \# studies \\
\hline Textile Mill Industry & 3 \\
Primary Metal Industry & 4 \\
Leather Industry & 1 \\
\hline Rubber and Miscelleous Plastic Industry & 2 \\
\hline Transportation Equipment Industry & 4 \\
\hline Cement Manufacturer Industry & 1 \\
\hline Chemical and Allied Industry & 2 \\
\hline Furniture and Fixtures Industry & 1 \\
\hline Food and Kindred Industry & 1 \\
\hline Industrial and Commercial Mechinery Industry & \\
\hline
\end{tabular}

Table 4 Risk Factors 


\begin{tabular}{|c|c|c|c|c|c|c|}
\hline$\overline{\text { NO }}$ & Author & Title & $\begin{array}{c}\text { Data } \\
\text { Collection }\end{array}$ & $\begin{array}{c}\text { Sample } \\
\text { Size }\end{array}$ & $\begin{array}{c}\text { Significant } \\
\text { Risk Factors }\end{array}$ & $\begin{array}{c}\text { Noise } \\
\text { Intensity }\end{array}$ \\
\hline 1 & $\begin{array}{l}\text { Marlina et } \\
\text { al., } 2016\end{array}$ & $\begin{array}{l}\text { Analisis Faktor Risiko Gangguan } \\
\text { Pendengaran } \\
\text { Sensorineural Pada Pekerja Pt. X } \\
\text { Semarang }\end{array}$ & Indonesia & 66 & $\begin{array}{c}\text { Noise } \\
\text { intensity, age, } \\
\text { hypertension }\end{array}$ & $>85 \mathrm{~dB}$ \\
\hline
\end{tabular}

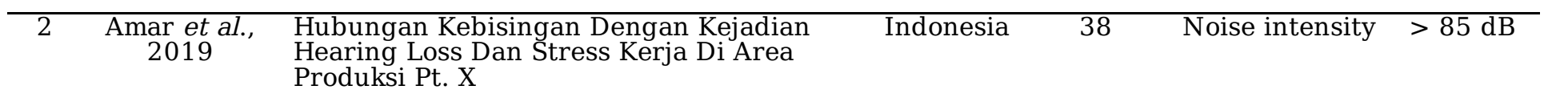

\begin{tabular}{|c|c|c|c|c|c|c|}
\hline 3 & $\begin{array}{l}\text { Minggarsari } \\
\text { \& Sahuri, } \\
2019\end{array}$ & $\begin{array}{l}\text { Hubungan Intensitas Kebisingan Dengan } \\
\text { Keluhan Auditori Pada Pekerja Bagian } \\
\text { Produksi Pabrik Fabrikasi Baja }\end{array}$ & Indonesia & 80 & Noise intensity & $>85 \mathrm{~dB}$ \\
\hline 4 & $\begin{array}{l}\text { Azzahri \& } \\
\text { Indriani, } \\
2019\end{array}$ & $\begin{array}{l}\text { Faktor-Faktor Yang Berhubungan Dengan } \\
\text { Keluhan Pendengaran Pada Pekerja } \\
\text { Dibagian Produksi } \\
\text { Di Pt. Hervenia Kampar Lestari }\end{array}$ & Indonesia & 92 & $\begin{array}{c}\text { Noise } \\
\text { intensity, } \\
\text { length of work, } \\
\text { usage of HPD }\end{array}$ & $>85 \mathrm{~dB}$ \\
\hline
\end{tabular}

\begin{tabular}{|c|c|c|c|c|c|}
\hline 5 & $\begin{array}{l}\text { Syah\& } \\
\text { Keman } \\
(2017)\end{array}$ & $\begin{array}{l}\text { Pengaruh Penggunaan Pelindung Telinga } \\
\text { Dan Earphone } \\
\text { Terhadap Noise Induced Hearing Loss } \\
\text { Dan Tinitus Pada } \\
\text { Pekerja Bengkel }\end{array}$ & Indonesia & 37 & $\begin{array}{l}\text { Usage of HPD, } \\
\text { tinnitus and } \\
\text { use of } \\
\text { earphone }\end{array}$ \\
\hline
\end{tabular}

\begin{tabular}{|c|c|c|c|c|c|c|}
\hline 6 & $\begin{array}{l}\text { Arianto \& } \\
\text { Saptadi, } \\
2019\end{array}$ & $\begin{array}{l}\text { Faktor Penyebab Hearing Loss Pada } \\
\text { Pekerja Di Bagian Produksi Pt. Adi Satria } \\
\text { Abadi, Yogyakarta }\end{array}$ & Indonesia & 70 & $\begin{array}{c}\text { Noise } \\
\text { intensity, age, } \\
\text { usage of HPD } \\
\text { and smoking } \\
\text { habits }\end{array}$ & $>85 \mathrm{~dB}$ \\
\hline 7 & $\begin{array}{l}\text { Kesuma \& } \\
\text { Nasution, } \\
2019\end{array}$ & $\begin{array}{l}\text { Risk Factors Analysis Of Hearing Disorders } \\
\text { Due To Noise On Machinery Workers At } \\
\text { Universal Steel Factory }\end{array}$ & Indonesia & 30 & $\begin{array}{c}\text { Age, working } \\
\text { period, noise } \\
\text { intensity, } \\
\text { smoking habits }\end{array}$ & $>85 \mathrm{~dB}$ \\
\hline
\end{tabular}

\begin{tabular}{|c|c|c|c|c|c|c|}
\hline 8 & $\begin{array}{l}\text { Rahayu \& } \\
\text { Pawenang } \\
2016\end{array}$ & $\begin{array}{l}\text { Faktor Yang Berhubungan Dengan } \\
\text { Gangguan } \\
\text { Pendengaran Pada Pekerja Yang Terpapar } \\
\text { Bising Di Unit } \\
\text { Spinning I Pt. Sinar Pantja Djaja } \\
\text { Semarang }\end{array}$ & Indonesia & 44 & $\begin{array}{c}\text { Age, job } \\
\text { position, noise } \\
\text { intensity, } \\
\text { working period }\end{array}$ & $>85 \mathrm{~dB}$ \\
\hline 9 & $\begin{array}{c}\text { Hidayat et } \\
\text { al., } 2019\end{array}$ & $\begin{array}{l}\text { Faktor Risiko Gangguan Pendengaran } \\
\text { Pada Pekerja Di Bagian Produksi Pt. } \\
\text { Semen Tonasa Kab Pangkep }\end{array}$ & Indonesia & 50 & $\begin{array}{l}\text { Noise } \\
\text { intensity, } \\
\text { length of work, } \\
\text { working } \\
\text { period, usage } \\
\text { of HPD }\end{array}$ & $>85 \mathrm{~dB}$ \\
\hline 10 & $\begin{array}{l}\text { Marisdayana } \\
\text { et al., } 2016\end{array}$ & $\begin{array}{l}\text { Hubungan Intensitas Paparan Bising Dan } \\
\text { Masa Kerja Dengan Gangguan } \\
\text { Pendengaran } \\
\text { Pada Karyawan Pt. X }\end{array}$ & Indonesia & 101 & $\begin{array}{l}\text { Noise } \\
\text { intensity, } \\
\text { working } \\
\text { period, length } \\
\text { of work }\end{array}$ & $>85 \mathrm{~dB}$ \\
\hline
\end{tabular}

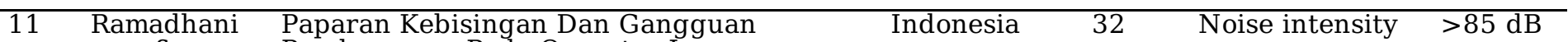
$\& \quad$ Pendengaran Pada Operator Lapangan

Firdausiana, Area 2020 Compressor House 


\begin{tabular}{|c|c|c|c|c|}
\hline 12 & $\begin{array}{c}\text { Kusumadewi } \\
\text { et al., } 2018\end{array}$ & $\begin{array}{l}\text { Faktor Risiko Yang Berhubungan Dengan } \\
\text { Kejadian Peningkatan Nilai Ambang } \\
\text { Dengar Pada Pekerja Di Bagian Produksi } \\
\text { Body Mini Bus Pt. X Magelang }\end{array}$ & $\begin{array}{ll}\text { Indonesia } & 57\end{array}$ & $\begin{array}{c}\text { Noise } \\
\text { intensity,age, } \\
\text { working period }\end{array}$ \\
\hline
\end{tabular}

\begin{tabular}{|c|c|c|c|c|c|c|}
\hline 13 & $\begin{array}{l}\text { Suryani et } \\
\text { al., } 2015\end{array}$ & $\begin{array}{l}\text { Analisis Gangguan Pendengaran Tipe } \\
\text { Sensorineural Pada Pekerja Akibat } \\
\text { Kebisingan Di Industri Mebel Kayu Di } \\
\text { Kota Pekanbaru }\end{array}$ & Indonesia & 27 & $\begin{array}{c}\text { Working } \\
\text { period and age }\end{array}$ & $>85 \mathrm{~dB}$ \\
\hline 14 & $\begin{array}{l}\text { Ibrahim et } \\
\text { al., } 2016\end{array}$ & $\begin{array}{l}\text { Faktor-Faktor Yang Berhubungan Dengan } \\
\text { Keluhan Gangguan Pendengaran Pada } \\
\text { Tenaga Kerja Bagian Produksi Pt. Japfa } \\
\text { Comfeed Indonesia, Tbk. Unit Makassar } \\
\text { Tahun } 2014\end{array}$ & Indonesia & 46 & $\begin{array}{c}\text { Noise } \\
\text { intensity, } \\
\text { length of work, } \\
\text { working } \\
\text { period, age } \\
\text { and usage of } \\
\text { HPD }\end{array}$ & $>85 \mathrm{~dB}$ \\
\hline
\end{tabular}

\begin{tabular}{|c|c|c|c|c|c|c|}
\hline 15 & $\begin{array}{l}\text { Jeffree et al., } \\
\quad 2016\end{array}$ & $\begin{array}{l}\text { Hearing Impairment And Contributing } \\
\text { Factors Among Fertilizer Factory Workers }\end{array}$ & Malaysia & $\begin{array}{c}49 \\
\text { cases } \\
\text { and } 98 \\
\text { male } \\
\text { subjects }\end{array}$ & $\begin{array}{c}\text { Noise } \\
\text { intensity, } \\
\text { working } \\
\text { period, usage } \\
\text { of HPD, } \\
\text { smoking habits } \\
\text { and age }\end{array}$ & $>85 \mathrm{~dB}$ \\
\hline 16 & $\begin{array}{l}\text { Sriopas et } \\
\text { al., } 2017\end{array}$ & $\begin{array}{l}\text { Occupational Noise-Induced Hearing Loss } \\
\text { In Auto Part Factoryworkersin Welding } \\
\text { Units In Thailand }\end{array}$ & Thailand & 180 & $\begin{array}{c}\text { Noise } \\
\text { intensity, } \\
\text { smoking } \\
\text { habits, } \\
\text { working period }\end{array}$ & $>85 \mathrm{~dB}$ \\
\hline 17 & $\begin{array}{l}\text { Chen et al., } \\
2019\end{array}$ & $\begin{array}{l}\text { Prevalence and determinants of noise- } \\
\text { induced hearing loss among workers in the } \\
\text { automotive industry in China: A pilot study }\end{array}$ & China & 6557 & $\begin{array}{l}\text { Noise intensity } \\
\text { and usage of } \\
\text { HPD }\end{array}$ & $\geq 80 \mathrm{~dB}$ \\
\hline
\end{tabular}

\begin{tabular}{|c|c|c|c|c|c|c|}
\hline 18 & $\begin{array}{c}\text { Zaw et al., } \\
2020\end{array}$ & $\begin{array}{l}\text { Assessment of Noise Exposure and } \\
\text { Hearing Loss Among Workers inTextile } \\
\text { Mill (Thamine), Myanmar: A Cross- } \\
\text { Sectional Study }\end{array}$ & Myanmar & 226 & $\begin{array}{l}\text { Age, education } \\
\text { levels, hearing } \\
\text { difficulty, } \\
\text { tinnitus, } \\
\text { hypertension, } \\
\text { working } \\
\text { period }\end{array}$ & $>85 \mathrm{~dB}$ \\
\hline 19 & $\begin{array}{c}\text { Khaldari et } \\
\text { al., } 2020\end{array}$ & $\begin{array}{l}\text { The Relation between Hearing Loss and } \\
\text { Smoking among Workers Exposed to } \\
\text { Noise, Using Linear Mixed Models }\end{array}$ & Iran & 272 & Smoking habits & $>85 \mathrm{~dB}$ \\
\hline
\end{tabular}

\begin{tabular}{cclrrr}
\hline 20 & $\begin{array}{c}\text { Abraham et } \\
\text { al., 2019 }\end{array}$ & $\begin{array}{l}\text { Prevalence of Noise-Induced Hearing Loss } \\
\text { among Textile Industry Workers in Dar es } \\
\text { Salaam, Tanzania }\end{array}$ & Tanzania & 265 & Age and \\
& & & working period
\end{tabular}

\section{Discussion}

In the context of this study, the distribution of risk factors for NIHL in a given population can help identify group at the greatest risk for an early detection of the interference that might occur. 
Unfortunately, in this review only one longitudinal study and one case control study were found. Meanwhile the majority (90\%) of the studies in this review were cross sectional studies. This could not generalize the results of the risk factors as a cross-sectional study did not reveal any definite cause-andeffect relationship. However, some general comments can be made about the study results.

In this study, risk factors can be seen as factors related with noise exposure (noise intensity, years of service and duration of work), demographics factors (gender, age, education level, and job position), medical conditions, and risk behaviors (smoking, non-occupational noise exposure) and Hearing Protection Device (HPD) usage.

Noise intensity that exceeds threshold value ( $>85 \mathrm{dBA})$ is the strongest risk factor in influencing the occurrence of $\mathrm{NIHL}$ among workers in the manufacturing industries.

This study confirms an evidence regarding the years of service, that indicated the impact of noise is unlikely to be seen in workers with relatively short exposure durations ( $<5$ years). Hence, the impact of noise will be found as the duration increases, workers who have worked for over 5 years have a greater risk of suffering from NIHL. Different types of work may have different conditions of noise exposure, leading to a differed prevalence of NIHL among workers (Chen et al., 2019). In short, within 10-15 years workers may encounter the tearing of the hair cells in the cortiary organs which will cause a total destruction of cortiary organs (Kusumadewi et al., 2018). Continuous exposure at least ( $\geq 85 \mathrm{~dB}$ ) for 5 years increases the risk of NIHL (Sriopas et al., 2017).

The result was consistent with the duration of the exposure (hours). That indicated, workers who were exposed to $>8$ hours/day and 40 hours/week increased the risk of NIHL. Therefore the longer the exposure, the greater the risk of $\mathrm{NIHL}$ occured.

As for demographic factors, this study finds that the risk of $\mathrm{NIHL}$ increases in workers aged $\geq 40$ years. Workers aged ( $\geq 40$ years) are a group of workers who are vulnerable to suffering from NIHL. The biological explanation for this effect is that when age increases, there will be a decrease in the physiological function of the body and thus have an impact on their auditory system (presbycusis). As someone's getting older there is a process of degeneration of the hearing organs, specifically cochlea (Marlina et al., 2016; Kusumadewi et al., 2018).

On the other hands, gender are not significantly link to NIHL. Its likely due to disproportionate number of workers which are dominated by male in a more noisy area, where the operation is carried out by male, therefore, gender does not have a significant effect on the prevalence of NIHL among manufacturing industries. Further studies should investigate noise exposure levels in females and workers in other occupations or areas who have been exposed to noise levels similar to those in the current studies.

The level of education may affect the abilities and skills of workers in carrying out their work (Suryani et al., 2015). However, the level of education does not directly affect the occurrence of hearing loss. Things 
that may be more influential are compliance with policies, safety culture, and workers' perceptions of noise risk (Sriopas et al., 2017).

This study suggets that workers with high blood pressure have a higher prevalence of NIHL. Workers with hypertension was significantly related with NIHL. Meanwhile for other medical conditions such as Hypercholesterolemia, hyperglycemia, Diabetes Mellitus, headaches, earaches were not statistically significant with the occurence of NIHL. In addition, the study found that if tinnitus is severe, it can lead to the occurrence of NIHL (Syah and Soedjajadi, 2017). So that tinnitus might be a risk factor for NIHL. However, workers with hearing impairment may not notice a change in hearing ability until a large shift in threshold occurs. And on further exposure, there will be permanent hearing loss and can increase in severity with continued exposure (Zaw et al., 2020).

The link between NIHL and smoking habit has still not been firmly established. Study by Khaldari et al (2020) showed that smoking alone does not have a significant effect on hearing loss. The findings showed that smoking when associated with noise can increase the occurrence of hearing loss in one or even both ears. Further analysis found that the higher the cigarettes consumed, the higher the toxic substances that will be received. Cigarettes have ototoxic substances, such as nicotine and carbon monoxide in it. Ototoxic substances can lead to circulatory cochlear stenosis (Sriopas et al., 2017; Arianto and Saptadi, 2019).

Based on the analysis, loud noise exposure (e.g. leisure noise exposure, loud music listening, hunting habits and activities using firearms). Unfortunately, the study didn't find any direct relation between loud noise exposure and NIHL among manufacturing workers. This could be caused by inadequate documentations based on the studies.

The occurrence of NIHL can also be affected by the usage of Hearing Protection Device (HPD). These findings suggest that the high prevalence of $\mathrm{NIHL}$ based on the studies were due to the lack of HPD usaged.

Based on these studies, the lack usage of HPD were due to the unavailability, the lack of discipline, convenience and the worker's perceptions of using HPD. This is in line with NIOSH (1998), that stated one of the determining factors in employee acceptance of the consistent use of HPD is convenience (National Institute for Occupational Safety and Health, 1998).

Some limitations in this study should also be considered. First, related to the small number of studies reviewed. This this may be due to the small number of databases used and it may have been jeopardized by the strategies used, such as key words and limiting the search to the advanced form.

A second limitation was contributed through the wide and distinctive definition or classification of risk factor in the groups. Some numerical variables such as noise level, age, and working period had different cutoffs among the studies. 
Majority of the studies were cross sectional studies. So it is difficult to determine the cause-and-effect relationship between $\mathrm{NIHL}$ and its risk factors. Further research is needed with a higher design to analyze this. In addition, these studies were conducted with the purpose of investigating risk factors specifically for NIHL and this may have introduced some bias in to the characteristics of the samples. And this study may also have introduced some more bias as the literature search was limited to published primary research studies written in english or indonesian. So this could not generalize the results to other group population as there may be other risk factor identified in other studies that are published in different languages.

Further-more, given the limitations discussed above, there is a lot of scope and future work that can be recommended based on this systematic review. The identified significant risk factors can be stratified according to their effectiveness in predicting the occurrence of NIHL.These will highlight workers who are most vulnerable and need special attention. Therefore it will be necessary to develop more studies that are carefully designed for this population.

\section{Conclusion}

Based on the results of the systematic reviews of the 20 studies above, it is concluded that the most important finding in this study is that factors related with noise exposure such as noise intensity, years of service and length of work have a major role in the incidence of NIHL in manufacturing industry workers. Then, demographic factors such as age and medical conditions (history of hearing loss and hypertension) also play a role in the incidence of NIHL. While risk behaviors such as smoking and nonoccupational noise exposure are risk factors that do not have a direct influence on NIHL, these risk factors do not affect an individual's vulnerability if they are not associated with other risk factors over a period of time.

Preventive actions with a focus on education in schools, implementation of regulations and legislation, with proper HPDs are important first lines of defense in overcoming hearing loss. Further studies need to be done to get a more accurate concept of the risk factors for NIHL.

\section{Declarations}

\section{ACKNOWLEDGEMENTS}

The authors would like to thank all parties who cannot be mentioned individually who have helped carry out this research to completion.

Competing interests: The authors declare no competing interests.

\section{References}


Amar, D. M., Lusiana, D. and Nuryanto, M. K. (2019) ‘Hubungan kebisingan dengan kejadian Hearing Loss dan Stress Kerja di Area Produksi PT.X', Husada Mahakam: Jurnal Kesehatan, 5(1), pp. 1-12.

Arianto, M. E. and Saptadi, J. D. (2019) 'Faktor Penyebab Hearing Loss Pada Pekerja Di Bagian Produksi Pt. Adi Satria Abadi, Yogyakarta', Jurnal Publikasi Kesehatan Masyarakat Indonesia, 6(1), pp. 15-20.

Centers for Disease Control and Prevention (CDC). (2020) Preventing Noise-Induced Hearing Loss. Available at: https://www.cdc.gov/ncbddd/hearingloss/noise.html.

Chen, Y. et al. (2019) 'Prevalence and determinants of noise-induced hearing loss among workers in the automotive industry in China: A pilot study', Journal of Occupational Health, 61(5), pp. 387-397.

European Agency for Safety and Health at Work (EU-OSHA). (2009) Combined exposure to noise and ototoxic substances. Available at: http://europa.eu.

Hidayat, Purnawaty, K. and Dahliyani, A. S. (2019) 'Faktor Risiko Gangguan Pendengaran Pada Pekerja Di Bagian Produksi Pt. Semen Tonasa Kab Pangkep', Sulolipu: Media Komunikasi Sivitas Akademika dan Masyarakat, 19(2), p. 187.

International Labour Organization (2014) Physical Hazards - Noise. Available at: https://www.ilo.org/wcmsp5/groups/public/--americas/--ro-lima/--sroport_of_spain/documents/presentation/wcms_250190.pdf.

Jamal, A. et al. (2016) 'Noise Induced Hearing Loss and Its Determinants in Workers of an Automobile Manufacturing Unit in Karachi, Pakistan', Madridge J Otorhinolaryngol, 1(1), pp. 1-11.

Kusumadewi, I. P. et al. (2018) 'Faktor Risiko yang Berhubungan dengan Kejadian Peningkatan Nilai Ambang Dengar pada Pekerja di Bagian Produksi Body Mini Bus PT. X Magelang', Jurnal Kesehatan Masyarakat (e-Journal), 6(5), pp. 549-555. 
Marlina, S., Suwondo, A. and Jayanti, S. (2016) 'Analisis Faktor Risiko Gangguan Pendengaran Sensorineural Pada Pekerja Pt. X Semarang', Jurnal Kesehatan Masyarakat (e-Journal), 4(1), pp. 359366.

NIOSH ( National Institute for Occupational Safety and Health) (1998) Occupational noise exposure, DHHS (NIOSH) Publication No. 98-126. Available at: http://www.cdc.gov/niosh/docs/98-126/.

PERMENAKER (2018) Peraturan Menteri Ketenagakerjaan Republik Indonesia Nomor 5 Tahun 2018 Tentang Keselamatan Dan Kesehatan Kerja Lingkungan Kerja. Jakarta: Ministry of Manpower and Transmigration.

Sari, M. A. et al. (2017) 'The correlation of smoking and noise induced hearing loss on workers at a palm oil factory X in Medan-Indonesia', Bali Medical Journal (Bali Med J), 6(3), pp. 637-640.

Sriopas, A. et al. (2017) 'Occupational noise-induced hearing loss in auto part factory workers in welding units in Thailand', Journal of Occupational Health, 59(1), pp. 55-62.

Suma'mur (2014) Higiene Perusahaan dan Kesehatan Kerja (Hiperkes) Edisi 2. Jakarta: CV Sagung Seto.

Suryani, Mulyadi, A. and Afandi, D. (2015) 'Analisis Gangguan Pendengaran Tipe Sensorineural Pada Pekerja Akibat Kebisingan Di Industri Mebel Kayu Di Kota Pekanbaru', Jurnal Ilmu Lingkungan, 9(1), pp. $1-11$.

Syah, P. B. and Soedjajadi, K. (2017) 'Effect of Using Hearing Protection and Earphone on Noise Induced Hearing Loss and Tinnitus in Workshop's Workers', Jurnal Kesehatan Lingkungan, 9(1), pp. 21-30.

World Health Organization (WHO). (2015) Hearing loss due to recreational exposure to loud sounds. 
World Health Organization(WHO). (2017a) Determination of Risk of Noise-Induced Hearing Loss due to Recreational Sound: Review.

World Health Organization (WHO). (2017b) WHO Europe GBD Data and statistics - Occupational health. Available at: https://www.euro.who.int/en/health-topics/environment-and-health/occupationalhealth/data-and-statistics.

Zamri, M. et al. (2017) 'Predictors of Aircraft Related Noise Induced Hearing Loss (NIHL) Among Technicians in Royal Malaysian Air Force (RMAF)', International Journal of Public Health and Clinical Sciences, 4(3), pp. 120-130.

Zaw, A. K. et al. (2020) 'Assessment of Noise Exposure and Hearing Loss Among Workers in Textile Mill (Thamine), Myanmar: A Cross-Sectional Study', Safety and Health at Work, 11(2), pp. 199-206.

\section{Figures}



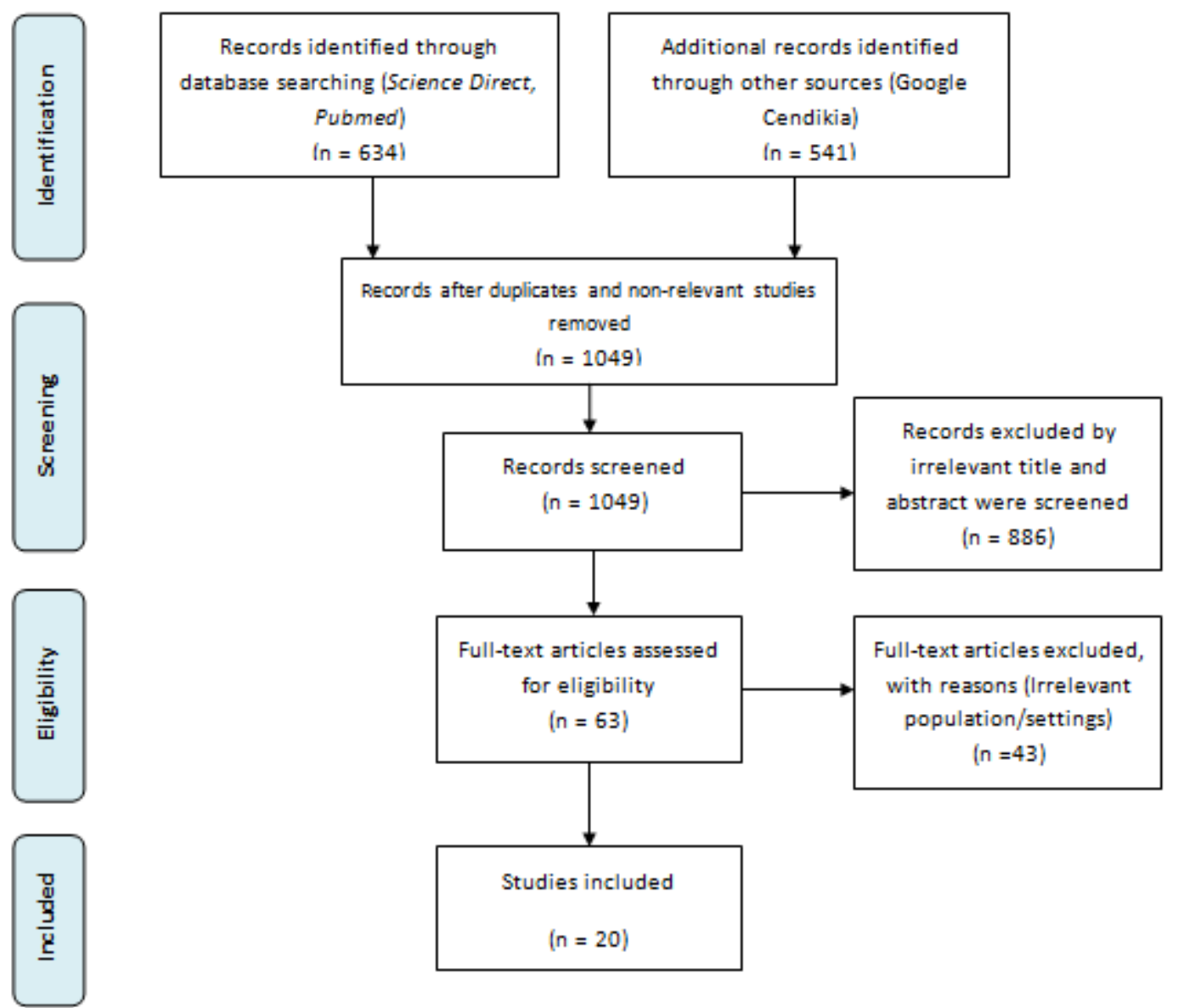

Figure 1

PRISMA (Preferred Reporting Items for Systematic Reviews and Meta-analyses) flow diagram of study selection.

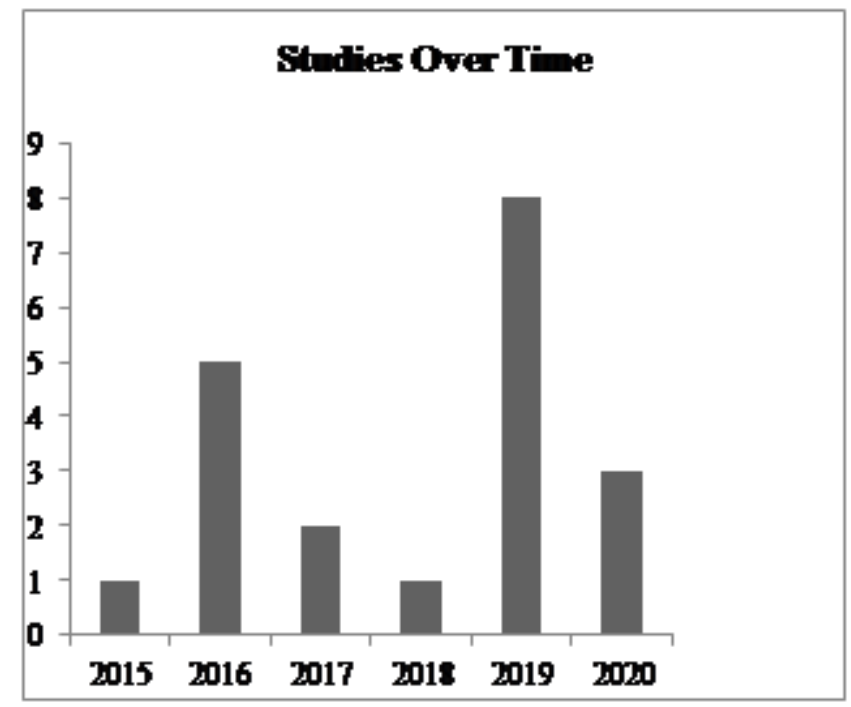

Figure 2

Distribution of studies over time 